\title{
Customer Engagement and Loyalty: A Comparative Study Between Service Contexts
}

\author{
Teresa Fernandes and Fabia Esteves \\ Faculty of Economics, University of Porto, Porto, Portugal
}

\begin{abstract}
The article discusses the effect of context on customer engagement and presents propensity to engage as an attitudinal antecedent of loyalty behaviors. We argue that customers may hold different propensity to engage depending on the specific service context, which in turn will influence more or less favorable behaviors. Data were collected through a convenience sample of 516 consumers in two settings, high and low contact services. Results revealed that propensity to engage and loyalty behaviors vary significantly between the contexts studied. We also conclude that the majority of loyalty behaviors are correlated, in both contexts, with customers' propensity to engage.
\end{abstract}

\section{KEYWORDS}

Customer engagement; customer loyalty; propensity to engage; services

\section{Introduction}

Increasingly, long-term, sustainable competitive advantages depend on the firm's ability to retain, sustain, and nurture its customer base (Anderson, Fornell, \& Mazvancheryl, 2004; Gruca \& Rego, 2005; Rego et al., 2009; Van Doorn et al., 2010). Customer relationships became one of the main issues in marketing, with several authors emphasizing its importance in business.

Customer engagement (CE) refers to a broader "transcending" relational perspective (Vargo, 2009) and is described as a significant tool for building and improving relationships with customers, namely service relationships (Brodie, Hollebeek, Juric, \& Ilic, 2013). Engagement implies a deeper relationally based level and, thus, has an important place in contributing to the understanding of customer outcomes, namely loyalty-related outcomes (Bowden, 2009). Correspondingly, Verhoef et al. (2010) revealed the increasing trend in companies trying to encourage their customers to involve in this kind of nontransactional behaviors that go beyond purchase intentions.

However, though the concept of $\mathrm{CE}$ is emerging in the marketing literature, research is still in its infancy (Brodie, Hollebeek, Juric, \& Ilic, 2011; Gambetti \& Graffigna, 2010; Hollebeeck, 2011a). Most studies are descriptive or conceptual in

CONTACT Teresa Fernandes $\otimes$ tfernandes@fep.up.pt $\Theta$ Faculty of Economics, University of Porto, R Dr Roberto Frias, 4200-464, Porto, Portugal.

(c) 2016 Taylor \& Francis Group, LLC 
nature (e.g., Brodie et al., 2011; Sashi, 2012; Van Doorn et al., 2010; Vivek et al., 2012) and much of what has been written about engagement has its basis in management practice rather than in academic research (Bowden, 2009). Moreover, while CE is considered a multidimensional construct with cognitive, emotional and behavioral components, few empirical research focus the attitudinal antecedents of engagement Also, though CE is a context-dependent concept, most studies refer to specific settings (Vivek, 2009), namely online brand communities, instead of the "physical world," and thus these are fields that require further attention (Brodie et al., 2013). According to Brodie et al. (2011), engagement research across a wide range of service contexts is expected to contribute more effectively to furthering scholarly understanding of engagement processes.

The aim of this study is to discuss the effect of context as a factor that can facilitate and/or inhibit CE. We argue that customers may hold different propensity to engage in a relationship with their provider depending on the specific service context. Different propensities will, in turn, influence more or less favorable behavioral outcomes. We begin by presenting the literature relevant to this study, namely CE and customers' propensity to engage in relationships with their service providers. Next, we present the research methodology and discuss main results. Through a convenience sample of 516 consumers, we conduct a cross-sectional survey to examine differences in customers' propensity to engage and loyalty behaviors in two service settings, health care and retailing. Finally, we conclude the article by presenting final conclusions, contributions, and suggestions for future research.

\section{The concept of customer engagement}

Engagement was first conceptualized by Kahn (1990), who studied its psychological preconditions. Recently, organizations have been launching programs to engage customers and measuring levels of $\mathrm{CE}$ as a response to the growing resistance of consumers to traditional marketing programs (Bagozzi \& Dholakia, 2006). Since 2005, the term "engagement" has been increasingly used in the broader academic marketing literature (Brodie et al., 2011). However, in spite of the use of this term in recent practitioner and academic literature, systematic conceptualizations of engagement in marketing are scarce (Vivek et al., 2012) and a general consensus has not yet been reached (Hollebeeck, 2011a; Javornik \& Mandelli, 2013).

The definition presented by Brodie (2011) can be considered to be the most comprehensive CE definition in the literature. According to Brodie et al. $(2011,2013)$, CE represents a highly context-dependent psychological state, characterized by a specific intensity level that plays a center role in the process of relational exchange. Moreover, other relational concepts can act as antecedents and/or consequences in CE processes. As such, $\mathrm{CE}$ is defined as "a multidimensional concept comprising cognitive, emotional, and/or behavioral dimensions" (Brodie et al, 2011, p. 260). Also Patterson et al. (2006) defined CE as the level of a customer's physical, cognitive, and emotional presence in their relationship with a service organization. Engagement is acknowledged as a potentially highly context-specific variable that 
may impact consumer choice in relation to brands, products, or organizations (Patterson et al., 2006). Bowden (2009) described CE as "a psychological process" driving customer loyalty, and primarily concerned with examining the formation and development of customer relationships. Engagement is further characterized by differing levels, which are individual and/or context specific (Bowden, 2009; Sprott et al., 2009).

Though considered as a multidimensional construct, the behavioral dimension of CE appears as dominant in the literature (Brodie et al., 2011) and has been largely adopted (Javornik \& Mandelli, 2013). To authors such as Jakkola and Alexander (2014), Van Doorn et al. (2010), and Pham and Avnet (2009), engagement is defined primarily with reference to specific customer activity types or patterns. For these authors, the concept of $\mathrm{CE}$ aggregates the multiple ways customer behaviors beyond transactions may influence the firm (Jakkola \& Alexander, 2014). Customers engage in a number of behaviors that strengthen their relationship with the product, company, or brand that go beyond mere purchasing behavior (Gummerus et al., 2012), including also word-of-mouth (WOM), recommendations, cross-buying, and active voice/complaints (Van Doorn et al., 2010). Furthermore, engaged customers are expected to show a stronger preference for premium products and lower price sensitivity (Ramkumar et al., 2013), proving to be more profitable than their nonengaged counterparts (Voyles, 2007). These loyalty-related outcomes beyond purchase may be better predicted by $\mathrm{CE}$ than by other conventional marketing constructs such as quality or satisfaction, which fail to capture the depth of relationships consumers form with what they consume (Bowden, 2009; Hollebeek, 2011a, 2011b; Patterson et al., 2006). Namely, CE is anticipated to contribute to the core relationship marketing tenets of customer repeat patronage, retention, and loyalty (Verhoef et al., 2010). However, the potential contribution of engagement to customer loyalty is just now starting to transpire in the literature (Bowden, 2009), and corroboration of these contentions is yet to be undertaken through empirical research (Javornik \& Mandelli, 2012; Brodie et al., 2011; Roberts \& Alpert, 2010). Moreover, although the unidimensional approaches possess the merit of simplicity, they fall short in reflecting the rich conceptual scope of engagement (Brodie et al., 2011).

\section{Towards a multidimensional concept of customer engagement: Propensity to engage}

The prominent perspective of literature considers CE as a multidimensional construct with cognitive, emotional, and behavioral components. Nevertheless, over $40 \%$ of the definitions in the literature express engagement as a unidimensional concept, with the behavioral dimension appearing as dominant (Brodie et al., 2011). However, the most important factors affecting engagement are attitudinal antecedents (Van Doorn et al., 2010). Engaging in a relationship is not signaled only by behavior, but more by the attitudes and reasons why the behavior occurs (Venetis \& Ghauri, 2004). According to attitude research (Fishbein \& Ajzen, 1975), a person's behavior is determined by its intention to perform it. Intention has been 
viewed as the willingness to continue a course of action or activity, such as engaging in a relationship (Wetzels, et al., 1998), and would be closer to overt behavior than the cognitions and affective components on which they are based.

Several definitions emphasize the role of attitudes in the creation of a state of engagement. In the organizational behavior literature, employee engagement is argued to be positively related to an individual's attitudes, intentions, and behaviors (Saks, 2006). Bowden (2009) illustrated engagement as an iterative process, commencing with customer satisfaction and including attitudinal antecedents such as rational and emotional bonds, trust, and involvement, culminating in an end state of engaged and loyal customers. Also Vivek et al. (2012) stated that an engaged individual may develop more favorable attitudes toward a product, company, or brand, which strengthens the psychological process and increases the likelihood of a positive behavioral response.

A considerable body of consumer behavior literature has dealt with the attitudebehavior relationship. Perhaps the most popular is the framework developed by Dick and Basu (1994), in which a distinction is made between attitudinal and behavioral loyalty. The authors stated that loyalty has two dimensions: relative attitude and repeat patronage behavior. They identified four loyalty categories: loyalty (positive relative attitude, high repeat patronage), latent loyalty (positive relative attitude, but low repeat patronage), spurious loyalty (high repeat patronage, low relative attitude), and no loyalty (low on both dimensions). The high patronage of spurious loyal customers may be explained by factors such as habitual buying, financial incentives, convenience, and lack of alternatives. As such, the behavioral approach may not yield a comprehensive insight into the underlying reasons. Instead it is a consumer's disposition in terms of intentions that plays an important role (Fernandes \& Proença, 2013).

In this study, we define propensity to engage as representing a consumer's tendency or proneness to engage in relationships with providers of a particular product/service category, leading to different CE levels. The individual's propensity to engage has been referred to in the literature in reference to behaviors such as WOM, complaint behavior, or co-creation activities (Bijmolt et al., 2010; Bowden, 2009; Dellarocas \& Narayan, 2006; Fuchs, Prandelli, \& Schreier, 2010; Hoyer, Chandy, Dorotic, Krafft, \& Singh, 2010; Javornik \& Mandelli, 2012; Wirtz et al., 2013). Since consumers often vary highly in their willingness to engage, firms will be confronted with engaged-prone customers and "other customers" (Bijmolt et al., 2010). According to Brodie et al. (2011), CE levels may vary in a continuum, including customers that are "nonengaged," "marginally engaged," "engaged," and "highly engaged" (i.e., exhibiting different levels of cognitive, emotional, and/or behavioral engagement). Hollebeek (2011a) proposed an engagement-based segmentation framework, resulting in differentially engaged customer segments and different propensities to develop certain loyalty-related behaviors. Also, Bryson and Hand (2007) ranged customers from "actively disengaged" to "fully engaged." Identifying segments of consumers who are particularly willing to engage across the customer base may help companies to fine-tune their strategies. According to Van Doorn et 
al. (2010), customers can be classified and segmented according to "their propensity to engage and the types of engagement behaviors they display" (p. 263).

\section{The effect of context on engagement and propensity to engage}

Several factors may affect customers' propensity to engage and resulting levels of engagement. Van Doorn et al. (2010) suggested several factors that can facilitate and/or inhibit engagement, including context-based factors. Hollebeek (2011b) considered that the particular level of interactivity pertaining to specific engagement levels depends on factors such as particular contextual conditions. Moreover, according to Patterson et al. (2006), engagement levels may vary by factors including industry and product/service attributes. Vibert and Shields (2003) addressed the importance of considering the contextual nature of engagement. Brodie et al. (2011) stated that CE is subject to a context-and/or a stakeholder-specific expression.

In terms of context-based factors, engagement has been studied primarily in online settings, namely virtual brand communities (e.g., Brodie et al., 2013; Gummerus et al., 2012; Lee, Kim, \& Kim, 2011; Wirtz et al., 2013), given its conducive, interactive, and relationship centric nature (Tsai \& Men, 2013), while other settings remain largely unexplored in academic research. Nowadays, with communication technologies and information systems, it is possible to interact with and among consumers (Brodie et al., 2013). Online brand or user communities allow strengthening consumer relationships and engaging with brands (Bolton et al., 2013). Brand community members sharing an interest may create a bond (De Valck et al., 2009), turning the community into a powerful engagement platform (Shawhney et al., 2005).

Since engagement is a "context-dependent state of mind" (Hollebeek, 2011a, p. 790), contextual factors can affect customers' propensity to engage in service relationships and types of engagement behaviors displayed. For instance, engaging consumers is generally easier in high involvement, interaction-based contexts as opposed to low-involvement ones (Bolton \& Saxena-Iyer, 2009). With reduced services, commoditized products, increased availability, and reduced switching costs consumers may not attach much value to engage in a relationship with their provider (Pressey \& Mathews, 2000). Conversely, highly complex professional services may be situations for which customers may desire to engage in a relationship (Burnham, Frels, \& Mahajan, 2003; Harrisson-Walker, 2001; Venetis \& Ghauri, 2004).

However, the context-dependent perspective remains to be explored further on. Javornik and Mandelli (2012) studied the FMCG (fast-moving consumer goods) industry, a setting that can encounter challenges when trying to intensely engage and establish meaningful interactions with customers (Leahy, 2011). The authors studied levels of engagement of consumers in the industry through indicators such as willingness to repurchase, to recommend, and to complain. They concluded that loyalty is a significant characteristic of those who are willing to engage intensely and that engagement with FMCG brands is challenging and specific. In this sense, Javornik and Mandelli (2012) suggested that it would be important to investigate how $\mathrm{CE}$ differs across different industries, and discover how high (or low) is the 
willingness for CE within different product categories. In a study on online brand communities, Wirtz et al. (2013) considered that high involvement purchases and product complexity will moderate online brand communities' impact on engagement. The authors called for the need to further investigate how consumers can be segmented according to their propensity for engagement and what drives this engagement, namely comparing "contexts that differ in their focus" (p. 239). Also, according to Brodie et al. $(2011,2013)$ and Hollebeek (2011a), since engagement is a context-dependent concept, there is a need for comparative research across a wide range of service contexts, focusing not only online but also offline settings. Our study aims to address these literature gaps.

\section{Research framework and methodology}

Though the concept of CE is emerging in the marketing literature, there is still a lack of consensus regarding the nature of specific concepts as $\mathrm{CE}$ antecedents, concurrent factors, and/or consequences (Brodie et al., 2011; Hollebeeck, 2011a). The aim of this study is to investigate differences in customers' propensity to engage in a service relationship (attitudinal antecedent) and related loyalty outcomes (behavioral consequence), based on contextual factors (concurrent factor). We argue that customers may hold different propensity to engage in a service relationship given the context considered, and that these differences, in turn, affect the more or less favorable customer behaviors in the relationship. Though CE is anticipated to contribute to customer repeat patronage, retention, and loyalty (Verhoef et al., 2010), the potential contribution of engagement to customer loyalty is just now starting to transpire in the literature and is still underresearched (Bowden, 2009).

The empirical research was conducted in service contexts given its inherently relational nature (Grönroos, 2004) and the particular applicability of engagement in service settings, since its level of interactivity and reciprocal nature (Bolton \& Saxena-Iyer, 2009) is widely acknowledged (Bowden, 2009; Patterson et al., 2006). Two distinct service contexts were considered, defined according to the level of customer involvement with the service provider (Lovelock \& Wright, 2004). The first is health care services, where the consumer has a high degree of involvement with the service provider (physician), the service is personalized, and it is centered on people. High involvement services require greater investment in relationship building and offer higher levels of familiarity and trust, that would ultimately lead to the customization of the service (Ganesan-Lim, Russell-Bennett, \& Dagger, 2008) and higher levels of engagement (Bowden, 2009). Especially in medical service encounters, which are frequently characterized by a large degree of anxiety, patients desire to be acknowledged as people-they want to be listened to and treated with patience (Bloemer, deRuyter, \& Wetzels, 1999). Thus, in service industries such as health care, the benefits of engagement may go beyond mere consumption (Van Doorn et al., 2010). In our study, we have considered physicians/dentists, chosen by customers. The second context is retailing, where the degree of involvement with the customer 
is lower (Lovelock \& Wright, 2004). Low involvement is typical of discrete, routine, and mundane services, where the main emphasis is the standardization of processes (Ganesan-Lim et al., 2008). Services with a low degree of involvement with the customer tend to maximize the importance of highly structured actions to stimulate new business and are not based on personal and customized relations between the client and the provider (Folkes \& Patrick 2003). Specifically, services that offer standardized service solutions with moderate contact prioritize functional benefits (Paul et al., 2009). In our study, we have specifically considered the case of supermarketsa grocery and convenience retailer where the majority of transactions are "discrete, short-term, one-off acts" (Pressey \& Mathews, 2000, p. 273) and a transactional, rather than a relational approach may be the most appropriate (Gilbert \& Sumner, 2004).

Taking into account the contexts chosen, it becomes relevant to try to understand how CE differs according to the context analyzed. Different engagement propensities are predicted to generate distinct behavioral outcomes (Hollebeek, 2011a). It is thus significant (a) firstly, to assess the differences in customers' propensity to engage between the contexts presented in order to understand if this proneness changes from context to context; and (b) secondly, to make the same analysis for loyalty behaviors. The second part of the study analyzes the correlation, in both contexts, between customers' propensity to engage and key suitable dimensions of customer behaviors referred to in the literature. Namely, loyalty behaviors like repeat purchase, WOM, willingness-to-pay a price premium, and active voice/complaints, were all considered suitable for offline contexts and found consistent across different types of service industries (Bloemer et al., 1999). Attention is focused on testing the following hypotheses:

H1: There are significant differences between customers' loyalty behaviors in the health care context when compared with the retailing context.

H2: There are significant differences between customers' propensity to engage in a relationship in the health care context when compared with the retailing context.

H3: Customers' propensity to engage is correlated with customers' loyalty behaviors (WOM, repeat purchase, willingness-to-pay a price premium, and active voice/complaints) in both contexts.

Data were collected through a self-administered, online, cross-sectional survey. A convenience sample of 516 consumers was used to perform significance and correlation tests. In order to guarantee some level of engagement, and following Bowden's (2009) perspective on repeat customers, respondents were directed to think about specific providers (in health care and retailing) they patronized. Respondents were then asked to respond to the remaining questions focusing on that particular provider. The questionnaire was divided into three parts: the first part aimed to characterize the sample, the second part evaluated propensity to engage and customers' loyalty behaviors in the health care setting, and the third part evaluated propensity to engage and customers' loyalty behaviors in retailing. All constructs were measured based on multi-item scales established in previous research (Bloemer, 
Odekerken-Schröder, \& Kestens, 2003; Odekerken-Schröder et al., 2003; Zeithaml, Berry, \& Parasuraman, 1996) and assessed in a 7-point Likert scale $(1=$ completely disagree to $7=$ completely agree).

\section{Research findings}

The majority of the respondents (59.3\%) were female, between 25 and 34 years old (49.2\%), and with a bachelor's degree (40.9\%).

To verify $\mathrm{H} 1$ and $\mathrm{H} 2$, respectively, we performed independence $t$ tests in order to analyze differences between customers' behaviors (Table 1) and customers' propensity to engage (Table 2 ) in both contexts, item by item. For all items and dimensions, the average value assigned to the health care context is different from the average value assigned to the retailing context and the differences observed are statistically significant $(p=.000<.05)$. The only exception is the second item of the repeat purchase dimension.

Findings suggest that there are statistically significant differences in behavioral manifestations between the contexts analyzed (H1), with the exception of one item on the repeat purchase dimension. Thus, context seems to have an impact on behaviors that go beyond purchase. Health care customers tend to exhibit more favorable behaviors than retailing customers, since context conditions are more conducive. Namely, in the health care context, customers are more likely to spread WOM and less likely to be price sensitive, while in the retailing context customers are more likely to complain than in health care. Though customer feedback, particularly complaints, is considered as a manifestation of CE (e.g., Javornik \& Mandelli, 2012; Bijmolt et al., 2010), in the high involvement context customers seem to exhibit a noncomplaining behavior. One possible reason is that a sense of dependence and lack of control over the situation, like it may happen in a complex service like health care, can lead customers to avoid complaining in the event of a negative encounter (Tronvoll, 2011; Van Doorn et al., 2010). Conversely, in retailing services, where processes are more standardized and interaction is less personal, customers may find it less difficult to complain (Nimako \& Mensah, 2012).

As expected, it was also possible to verify that there are significant differences in customers' propensity to engage between the contexts analyzed (H2), in favor of the health care context, where customers have direct contact with the service provider and the degree of customization and interaction is higher.

To verify H3, we first performed an exploratory factorial analysis (Table 3). Four factors were extracted, referring to each one of the four behavioral manifestations considered (repeat purchase, WOM, price sensitivity, and complaints). The same was done for customers' propensity to engage, reaching accepted values for all constructs.

In order to verify the existence of a positive relationship between consumer relationship proneness and their behavioral intentions in both contexts (H3), a correlation analysis was performed. The results are presented in Table 4. 
Table 1. Hypothesis 1 testing results: student $t$ test performed to customer behaviors in both contexts.

\begin{tabular}{|c|c|c|c|c|c|c|}
\hline $\begin{array}{l}\text { Behavioral } \\
\text { Intentions }\end{array}$ & \multicolumn{2}{|c|}{ Items description } & $\begin{array}{l}\text { Average Healthcare } \\
\text { Context }\end{array}$ & $\begin{array}{l}\text { Average Retailing } \\
\text { Context }\end{array}$ & $t$ & Sig. \\
\hline \multirow{3}{*}{$\begin{array}{l}\text { Word of } \\
\text { Mouth } \\
\text { (WOM) }\end{array}$} & WOM1 & Say positive things & 5,11 & 4,64 & 5.95 & $0.000^{*}$ \\
\hline & WOM2 & $\begin{array}{l}\text { Recommend } X Y Z \text { to } \\
\text { someone who seeks } \\
\text { your advice }\end{array}$ & 5,08 & 4,74 & 4.11 & $0.000^{*}$ \\
\hline & WOM3 & $\begin{array}{l}\text { Encourage friends and } \\
\text { relatives to do business } \\
\text { with } X Y Z\end{array}$ & 4,71 & 4,25 & 5.17 & $0.000^{*}$ \\
\hline \multirow{3}{*}{$\begin{array}{l}\text { Repeat } \\
\text { Purchase } \\
\text { (RP) }\end{array}$} & $\begin{array}{l}\text { RP1 } \\
\text { RP2 }\end{array}$ & $\begin{array}{l}\text { Consider XYZ your first } \\
\text { choice to buy services }\end{array}$ & 5,33 & 4,92 & 4.79 & $0.000^{*}$ \\
\hline & & $\begin{array}{l}\text { Do more business with } \\
\text { XYZ in the next few } \\
\text { years }\end{array}$ & 4,14 & 4,17 & -0.33 & 0.744 \\
\hline & RP3 & $\begin{array}{l}\text { Do less business with XYZ } \\
\text { in the next few years }\end{array}$ & 2,92 & 3,16 & -2.87 & $0.004^{*}$ \\
\hline \multirow[t]{3}{*}{$\begin{array}{l}\text { Price } \\
\text { Sensitivity } \\
\text { (PS) }\end{array}$} & PS1 & $\begin{array}{l}\text { Take some of your } \\
\text { business to a } \\
\text { competitor that offers } \\
\text { better prices }\end{array}$ & 3,33 & 5,63 & -25.29 & $0.000^{*}$ \\
\hline & PS2 & $\begin{array}{l}\text { Continue to do business } \\
\text { with XYZ if its prices } \\
\text { increase somewhat }\end{array}$ & 4,64 & 3,09 & 19.23 & $0.000^{*}$ \\
\hline & PS3 & $\begin{array}{l}\text { Pay a higher price than } \\
\text { competitors charge for } \\
\text { the benefits you } \\
\text { currently receive from } \\
\text { XYZ }\end{array}$ & 4,14 & 2,74 & 16.3 & $0.000^{*}$ \\
\hline \multirow[t]{4}{*}{$\begin{array}{l}\text { Complaints } \\
\text { (C) }\end{array}$} & $\mathrm{C} 1$ & $\begin{array}{l}\text { Switch to a competitor if } \\
\text { you experience a } \\
\text { problem with XYZ's } \\
\text { service }\end{array}$ & 4,97 & 5,21 & -2.98 & $0.003^{*}$ \\
\hline & $\mathrm{C} 2$ & $\begin{array}{l}\text { Complain to other } \\
\text { customers if you } \\
\text { experience a problem } \\
\text { with XYZ's service }\end{array}$ & 4,89 & 5,38 & -7.47 & $0.000^{*}$ \\
\hline & $\mathrm{C} 3$ & $\begin{array}{l}\text { Complain to external } \\
\text { agencies, such as } \\
\text { consumer } \\
\text { organizations, if you } \\
\text { experience a problem } \\
\text { with XYZ's service }\end{array}$ & 3,55 & 4,33 & -11.69 & $0.000^{*}$ \\
\hline & C4 & $\begin{array}{l}\text { Complain to XYZ's } \\
\text { employees if you } \\
\text { experience a problem } \\
\text { with XYZ's service }\end{array}$ & 4,42 & 5,16 & -10.12 & $0.000^{*}$ \\
\hline
\end{tabular}

*Statistically significant at $\mathrm{p}<.05$.

Note. Adapted from Zeithaml, V., Berry, L.\& Parasuraman, A. (1996); Bloemer, J., Odekerken-Schröder, G. \& Kestens, L. (2003)

In both contexts, the correlations between customers' propensity of engage and WOM, repeat purchase and price sensitivity are significant $(p<.01)$. Repeat purchase and WOM have correlation coefficients larger than 0.5 , which means that there is a strong correlation in both contexts. Price sensitivity presents a moderate correlation with propensity to engage. In the case of complaints, both contexts show low, nonsignificant correlation coefficients (below 0.25). Following previous findings (H1), while some engaged customers may find that complaints are a second opportunity given to companies, others may feel uncomfortable complaining due to their loyalty to the firm (Nimako \& Mensah, 2012). Also, firms may need to 
Table 2. Hypothesis 2 testing results: student $t$ test performed to customers' propensity to engage in both contexts.

\begin{tabular}{|c|c|c|c|c|c|c|}
\hline & & Items description & $\begin{array}{l}\text { Average } \\
\text { Healthcare } \\
\text { Context }\end{array}$ & $\begin{array}{l}\text { Average Retailing } \\
\text { Context }\end{array}$ & $\mathrm{t}$ & Sig. \\
\hline \multirow[t]{3}{*}{$\begin{array}{l}\text { Customer Propensity to } \\
\text { Engage (CPE) }\end{array}$} & CPE1 & $\begin{array}{l}\text { Generally, I am someone } \\
\text { who likes to be a } \\
\text { regular customer of a } \\
\text { service provider }\end{array}$ & 5,19 & 4,69 & 6.36 & $0.000^{*}$ \\
\hline & CPE2 & $\begin{array}{l}\text { Generally, I am someone } \\
\text { who wants to be a } \\
\text { steady customer of the } \\
\text { same service provider }\end{array}$ & 5,33 & 4,52 & 10.63 & $0.000^{*}$ \\
\hline & CPE3 & $\begin{array}{l}\text { Generally, I am someone } \\
\text { who is willing to 'go } \\
\text { the extra mile' to } \\
\text { purchase at the same } \\
\text { service provider }\end{array}$ & 4,98 & 3,56 & 16.73 & $0.000^{*}$ \\
\hline
\end{tabular}

* Statistically significant at $\mathrm{p}<.05$.

Note. Adapted from Odekerken-Schröder, G., De Wulf, K. \& Schumacher, P. (2003).

Table 3. Exploratory factorial analysis results for customers' propensity to engage and customer behaviors in both contexts.

\begin{tabular}{|c|c|c|c|c|c|}
\hline $\begin{array}{l}\text { Customer } \\
\text { behaviors }\end{array}$ & Context & Number of components & KMO & Variance extracted \% & Cronbach's alpha \\
\hline \multirow[t]{2}{*}{ Word of mouth } & Health care & 3 & 0.71 & 82.67 & 0.892 \\
\hline & Retailing & 3 & 0.75 & 84.02 & 0.903 \\
\hline \multirow[t]{2}{*}{ Repeat purchase } & Health care & 3 & 0.67 & 64.13 & 0.718 \\
\hline & Retailing & 3 & 0.6 & 61.23 & 0.68 \\
\hline \multirow[t]{2}{*}{ Price sensitivity } & Health care & 3 & 0.64 & 65.58 & 0.727 \\
\hline & Retailing & 3 & 0.66 & 68.17 & 0.765 \\
\hline \multirow[t]{2}{*}{ Complaints } & Health care & 4 & 0.62 & 53.35 & 0.706 \\
\hline & Retailing & 4 & 0.7 & 56.96 & 0.74 \\
\hline \multirow{2}{*}{$\begin{array}{l}\text { Customer } \\
\text { propensity to } \\
\text { engage }\end{array}$} & Health care & 3 & 0.73 & 79.02 & 0.866 \\
\hline & Retailing & 3 & 0.68 & 81.74 & 0.886 \\
\hline
\end{tabular}

Table 4. Hypothesis 3 testing results: correlation between customers' propensity to engage and customer behaviors in both contexts.

\begin{tabular}{|c|c|c|c|c|}
\hline \multirow[b]{3}{*}{ Customer behaviors } & \multicolumn{4}{|c|}{ Customer propensity to engage } \\
\hline & \multicolumn{2}{|c|}{ Health care context } & \multicolumn{2}{|c|}{ Retailing context } \\
\hline & Pearson correlation & Sig. (two-tailed) & Pearson correlation & Sig. (two-tailed) \\
\hline Word of mouth & 0.506 & 0 & 0.511 & 0 \\
\hline Repeat purchase & 0.559 & 0 & 0.563 & 0 \\
\hline Price sensitivity & 0.463 & 0 & 0.452 & 0 \\
\hline Complaints & 0.02 & 0.649 & 0.109 & 0.013 \\
\hline
\end{tabular}

develop processes/platforms to support customer voice in order to influence subsequent behaviors like active voice (Van Doorn et al., 2010) and this may be a more relevant factor to facilitate and explain complaints than engagement. Finally, it is possible that complaining is determined by other antecedents besides engagement, such as the subjective probability that complaining will be successful, the attitude 
towards the act of complaining and the perceived cost of complaining (Bloemer et al., 1999).

\section{Conclusion}

The aim of this study was to examine the effect of context on CE, presenting propensity to engage as an attitudinal antecedent of customer loyalty behaviors. We argue that customers may hold different propensity to engage in a relationship with their provider depending on the specific service context. Different propensities will, in turn, influence more or less favorable customer behaviors. Results revealed that propensity to engage and customer behaviors vary significantly among the contexts studied. In the high involvement service (health care), customers exhibit higher propensity to engage and show more favorable behaviors, when compared with the low involvement service (retailing). It was also found that the majority of customer behaviors are, in both contexts, correlated with customers' propensity to engage. Only complaint behavior did not prove to be related with propensity to engage. Also, complaint behavior was found to be more likely in retailing when compared to health care. This may be due to the influence of other more important factors than engagement, such as personal (e.g., customer dependence, more likely in health care), situational (e.g., existence of standardized processes to complain, more likely in retailing), or the attitude towards the act of complaining.

Our study makes several contributions. Engagement research across a wide range of service contexts is required, since till now studies have been largely descriptive, conceptual, or managerial in nature and focused on specific online settings. Also, while the behavioral dimension of $\mathrm{CE}$ appears as dominant in the literature, few empirical research studies have focused on the attitudinal antecedents of $\mathrm{CE}$ and thus fall short in reflecting the rich conceptual scope of engagement. By investigating the effect of service context on CE, presenting propensity to engage as an attitudinal antecedent of customer behaviors using a large sample survey, our study contributes to bridge these literature gaps.

On a managerial level, the results of this study enhance insights on CE and are expected to be valuable for practitioners seeking to improve customer relationships, retention, and loyalty, namely according to their specific service context. For instance, in services like health care, high in credence qualities, WOM is particularly valuable and may be even more important than repurchase behavior. The more complex and variable the service, the more interested prospective customers are likely to be in the opinion of customers who have experienced it (Berry \& Seltman, 2007). These companies may be interested in targeting customers with a high propensity to WOM. According to Van Doorm et al. (2010), some companies reward customers for referrals, which may include social or expertise recognition. Also, firms may provide platforms to facilitate customer-to-customer (C2C) engagement. Mayo Clinic is an example within the health care sector that trusts WOM increasingly conveyed through social media and uses patients as advertisers for the brand (Berry \& Seltman, 2007). The results of this study also provide 
guidance to managers for segmenting customers according to their propensity to engage and the types of behaviors they display, instead of wasting resources with nonprone or unengaged consumers. For instance, customers who do not purchase a lot but exhibit many other loyalty outcomes may be a potential segment to deserve increase investment and nurturing by the firm.

However, this study is not without limitations. First, the limitations of data collection warrant caution in generalizing these results beyond the population sampled. Replication of this study with random sampling procedures would clearly add weight to the reported results. Second, further research using a longitudinal design could better address engagement processes dynamics (Brodie et al., 2011). This study could also be improved with access to database information on customer actual behavior history since measurements were based on self-reports. Also, while we used a traditional battery of customer loyalty behaviors, other "higher order" behaviors could be studied such as willingness to cooperate or acquiescence (Fernandes \& Proença, 2013; Jones \& Taylor, 2007). Additionally, a number of concurrent factors, such as firm or customer-based, not investigated here may prove to be significant to future studies. Future researchers may also consider replicating this study across other service contexts or even consumer goods to examine how our conclusions can apply in other purchase contexts.

\section{References}

Anderson, E., Fornell, C., \& Mazvancheryl, S. (2004, October). Customer satisfaction and shareholder value. Journal of Marketing, 68, 172-185.

Bagozzi, R., \& Dholakia, U. (2006). Antecedents consequences of customer participation in small group brand communities. International Journal of Research in Marketing, 23(1), 45-61.

Berry, L., \& Seltman, K. (2007). Building a strong services brand: Lessons from Mayo Clinic. Business Horizons, 50, 199-209.

Bijmolt, T., Leeflang, P., Block, F., Eisenbeiss, M., Hardie, B., Lemmens, A., \& Saffert, P. (2010). Analytics for customer engagement. Journal of Service Research, 13(3), 341-356.

Bloemer, J., deRuyter, K., \& Wetzels, M. (1999). Linking perceived service quality and service loyalty: a multi-dimensional perspective. European Journal of Marketing, 33(11/12), 10821106.

Bloemer, J., Odekerken-Schröder, G., \& Kestens, L. (2003). The impact of need for social affiliation and consumer relationship proneness on behavioral intentions: An empirical study in a hairdresser's context. Journal of Retailing and Consumer Services, 10(4), 231-240.

Bolton, R., Parasuraman, A., Hoefnagels, A., Michels, N., Kabadayi, S., Gruber, T., ... Solnet, D. (2013). Understanding Generation Y and their use of social media: A review and research agenda. Journal of Service Management, 24(3), 245-267.

Bolton, R., \& Saxena-Iyer, S. (2009). Interactive services: A framework, synthesis and research directions. Journal of Interactive Marketing, 23, 91-104.

Bowden, J. (2009). The process of customer engagement: A conceptual framework. Journal of Marketing Theory and Practice, 17(1), 63-74.

Bryson, C., \& Hand, L. (2007). The role of engagement in inspiring teaching and learning. Innovations in Education and Teaching International, 44(4), 349-362.

Brodie, R., Hollebeek, L., Juric, B., \& Ilic, A. (2011). Customer engagement: Conceptual domain, fundamental propositions, and implications for research. Journal of Service Research, 14(3), 252-271. 
Brodie, R., Hollebeek, L., Juric, B., \& Ilic, A. (2013). Consumer engagement in a virtual brand community: An exploratory analysis. Journal of Business Research, 66, 105-114.

Burnham, T., Frels, J., \& Mahajan, V. (2003). Consumer switching costs: A typology, antecedents and consequences. Journal of the Academy of Marketing Science, 31(2), 109-121.

Dellarocas, C., \& Narayan, R. (2006). A statistical measure of a population's propensity to engage in post-purchase online word-of-mouth. Statistical Science, 21(2), 277-285.

Dick, A., \& Basu, K. (1994). Customer loyalty: Toward an integrated conceptual framework. Journal of the Academy of Marketing Science, 22(2), 99-113.

Fernandes, T., \& Proença, J. (2013). Reassessing relationships in consumer markets: Emotion, cognition and consumer relationship intention. Journal of Relationship Marketing, 12(1), 4158.

Fishbein, M., \& Ajzen, I. (1975). Belief, attitude intention and behavior: An introduction to theory and research. Reading, MA: Addison-Wesley.

Folkes, V., \& Patrick, V. (2003, June). The positivity effect in perceptions of services: Seen one, seen them all? Journal of Consumer Research, 30, 135-137.

Fuchs, C., Prandelli, E., \& Schreier, M. (2010). The psychological effects of empowerment strategies on consumers' product demand. Journal of Marketing, 74(1), 65-79.

Gambetti, R., \& Graffigna, G. (2010). The concept of engagement: A systematic analysis of the ongoing marketing debate. International Journal of Market Research, 52(6), 801-826.

Ganesan-Lim, C., Russell-Bennett, R., \& Dagger, T. (2008). The impact of service contact type and demographic characteristics on service quality perceptions. Journal of Services Marketing, 22(7), 550-561.

Gilbert, D., \& Sumner, F. (2004). The current use of marketing in UK retailing. International Journal of Retail and Distribution Management, 32(5), 242-251.

Grönroos, C. (2004). The relationship marketing process: Communication, interaction, dialogue, value. Journal of Business and Industrial Marketing, 19(2), 99-113.

Gruca, T., \& Rego, L. (2005, July). Customer satisfaction, cash-flow and shareholder value. Journal of Marketing, 69, 115-130.

Gummerus, J. Liljander, V., Weman, E., \& Pihlström, M. (2012). Customer engagement in a Facebook brand community. Management Research Review, 35(9), 857-877.

Harrison-Walker, L. (2001). The measurement of word-of-mouth communication and an investigation of service quality and customer commitment as potential antecedents. Journal of Service Research, 4(1), 60-75.

Hollebeek, L. (2011a). Demystifying customer brand engagement: Exploring the loyalty nexus. Journal of Marketing Management, 27(7/8), 785-807.

Hollebeek, L. (2011b). Exploring customer brand engagement: Definition and themes. Journal of Strategic Marketing, 19(7), 555-573.

Hoyer, W., Chandy, R., Dorotic, M., Krafft, M., \& Singh, S. (2010). Consumer co-creation in new product development. Journal of Service Research, 13(3), 283-296.

Jaakkola, E., \& Alexander, M. (2014). The role of customer engagement behavior in value cocreation: A service system perspective. Journal of Service Research, 17(3), 247-261.

Javornik, A., \& Mandelli, A. (2013, July). Research categories in studying customer engagement. Paper presented at the Academy of Marketing (AM) Conference, Cardiff.

Javornik, A., \& Mandelli, A. (2012). Behavioral perspectives of customer engagement: An exploratory study of customer engagement with three Swiss FMCG brands. Journal of Database Marketing \& Customer Strategy Management, 19, 300-310.

Jones, T., \& Taylor, S. (2007). The conceptual domain of service loyalty: How many dimensions? Journal of Services Marketing, 21(1), 36-51.

Kahn, W. (1990). Psychological conditions of personal engagement and disengagement at work. Academy of Management Journal, 33(4), 629-724. 
Leahy, R. (2011). Relationships in fast moving consumer goods markets: The consumers' perspective. European Journal of Marketing, 45(4), 651-672.

Lee, D., Kim, H., \& Kim, J. (2011). The impact of online brand community type on consumer's community engagement behaviors: Consumer-created vs. marketer-created online brand community in online social-networking web sites. Cyberpsychology, Behavior, and Social Networking, 14(1/2), 59-63.

Lovelock, C., \& Gummesson, E. (2004). Whither services marketing? In search of a new paradigm and fresh perspectives. Journal of Service Research, 7(1), 20-41.

Nimako, S., \& Mensah, A. (2012). Motivation for customer complaining and noncomplaining behaviour towards mobile telecommunication services. Asian Journal of Business Management, 4(3), 310-320.

Odekerken-Schröder, G., \& Bloemer, J. (2004). Constraints and dedication as drivers for relationship commitment: An empirical study in a health-care context. Journal of Relationship Marketing, 3(1), 35-52.

Odekerken-Schroder, G., DeWulf, K., \& Schumacher, P. (2003). Strengthening outcomes of retailer-consumer relationships: The dual impact of relationship marketing tactics and consumer personality. Journal of Business Research, 56(3), 177-190.

Patterson, P., Yu, T., \& De Ruyter, K. (2006). Understanding customer engagement in services. Paper presented at the Australia-New Zealand Marketing Academy Conference: Advancing Theory, Maintaining Relevance, Proceedings, Brisbane, Australia.

Paul, M., Hennig-Thurau, T., Gremler, D., Gwinner, K., \& Wiertz, C. (2009). Toward a theory of repeat purchase drivers for consumer services. Journal of the Academy of Marketing Science, $37(2), 215-237$

Pham, M., \& Avnet, T. (2009). Rethinking regulatory engagement theory. Journal of Consumer Psychology, 19(2), 115-123.

Pressey, A., \& Mathews, B. (2000). Barriers to relationship marketing in consumer retailing. Journal of Services Marketing, 14(3), 272-286.

Rego, L., Billettt, M., \& Morgan, N. (2009, November). Consumer-based brand equity and firm risk. Journal of Marketing, 73, 47-60.

Ramkumar, R., Kumar, A., Janakiraman, R., \& Bezawada, R. (2013). The effect of customers' social media participation on customer visit frequency and profitability. Information Systems Research, 24(1), 108-127.

Roberts, C., \& Alpert, F. (2010). Total customer engagement: Designing and aligning key strategic elements to achieve growth. Journal of Product and Brand Management, 19(3), 198-209.

Sashi, C. (2012). Customer engagement, buyer-seller relationships, and social media. Management Decision, 50(2), 253-272.

Saks, A. (2006). Antecedents and consequences of employee engagement. Journal of Managerial Psychology, 21(7), 600-619.

Sprott, D., Czellar, S., \& Spangenberg, E. (2009, February). The importance of a general measure of brand engagement on market behavior: Development and validation of a scale. Journal of Marketing Research, 46, 92-104.

Tronvoll, B. (2011). Negative emotions and their effect on customer complaint behavior. Journal of Service Management, 22(1), 111-134.

Tsai, W., \& Men, L. (2013). Motivations and antecedents of consumer engagement with brand pages on social networking sites. Journal of Interactive Advertising, 13(2), 76-87.

Van Doorn, J., Lemon, K., Mittal, V., Nass, S., Pick, D., Pirner, P., \& Verhoef, P. (2010). Customer engagement behavior: Theoretical foundations and research directions. Journal of Service Research, 13(3), 253-266.

Vargo, S. (2009). Toward a transcending conceptualization of relationship: A service-dominant logic perspective. Journal of Business and Industrial Marketing, 24(5/6), 373-379. 
Venetis, K. \& Ghauri, P. (2004). Service quality and customer retention: Building long term relationships. European Journal of Marketing, 38(11/12), 1577-1598.

Verhoef, P., Reinartz, W., \& Krafft, M. (2010). Customer engagement as a new perspective in customer management. Journal of Service Research, 13(3), 247-252.

Vibert, A., \& Shields, C. (2003). Approaches to student engagement: Does ideology matter? McGill Journal of Education, 38(2), 221-240.

Vivek, S., Beatty, S., \& Morgan, R. (2012). Customer engagement: Exploring customer relationships beyond purchase. Journal of Marketing Theory \& Practice, 20(2), 127-145.

Voyles, B. (2007). Beyond loyalty: Meeting the challenge of customer engagement. Retrieved from http://www.adobe.com/engagement/pdfs/partI.pdf

Wirtz, J., Ramaseshan, B., van de Klundert, J., Canli, Z., \& Kandampully, J. (2013). Managing brands and customer engagement in online brand communities. Journal of Service Management, 24(3), 223-244.

Wetzels, M., deRuyter, K., \& Birgelen, M. (1998). Marketing service relationships: The role of commitment. Journal of Business and Industrial Marketing, 13, 406-423.

Zeithaml, V., Berry, L., \& Parasuraman, A. (1996, April). The behavioral consequences of service quality. Journal of Marketing, 60, 31-46. 